\title{
銅酸化膜の密着性と膜構造
}

\author{
宮沢 薰一*，三宅 淳司 ${ }^{* *}$, 波多野 隆紹**, 佐久間 健人*
}

\section{Adhesion and Structure of Copper Oxide Films}

Kun'ichi MIYAZAWA* , Junji MIYAKE ${ }^{* *}$, Takaaki HATANO** and Taketo SAKUMA*

*東京大学工学部材料学科 (于113 東京都文京区本郷7-3-1)

**日鉱金属株式会社倉見工場研究部（２53-01 神奈川県高坐郡寒川町倉見 3 ）

*Department of Materials Science, Faculty of Engineering, The University of Tokyo (7-3-1 Hongo, Bunkyo-ku, Tokyo 113)

**Research Department, Kurami Works, Nippon Mining and Metals Co., Ltd. (3 Kurami, Samukawa-cho, Koza-gun, Kanagawa 253-01)

\begin{abstract}
概要 純銅と種々の合金銅において，酸化膜の基材に対する密着性を，300，350，400 $\mathrm{C}$ のつの酸化温度につき，酸化膜 の剥離試験, XRD, SEM, TEM抢よびAESによって調べた。表面粗さを統した場合, 令試料の酸化膜の密着性は, 酸化温 度の上昇とともに低下した。タフピッチ銅が最も原い密着性の良い酸化膜を生じ，主として $\mathrm{Cu}_{2} \mathrm{O}$ 倠祭された。タフピッチ 銅の表面粗さを変化させた場合, 膜の密着性は表面粗度からは仳向が把握できなかったが, CuOの生成量の増加とともに低 下した。Cu-Ti合金の酸化膜は膜の密着性が少り，Tiの增加によりCuOがより多く観察されるようになった。CuOの生成が酸 化膜の密着性の低下に大きく関与していると考えられる。
\end{abstract}

\begin{abstract}
Adhesion of copper oxide films to the copper substrates was examined for pure coppers and various copper alloys oxidized at 300,350 and $400^{\circ} \mathrm{C}$ by the peeling test, XRD, SEM, TEM and AES of oxide films. In the specimens with the same surface roughness, the adhesion was degraded with increasing oxidation temperature. Tough pitch copper formed the thickest and most adhesive oxide film which had a major composition of $\mathrm{Cu}_{2} \mathrm{O}$. In the tough pitch copper specimens with different grades of surface roughness, the adhesion was degraded when the amount of $\mathrm{CuO}$ increased in the film. In $\mathrm{Cu}$-Ti alloys, the amount of $\mathrm{CuO}$ in the weakly bonded oxide film increased with increasing Ti-content. It is believed that the degradation of the adhesion is strongly related to the formation of $\mathrm{CuO}$ in the oxide film.
\end{abstract}

Key Words: Copper,Oxidation, Peeling Test, Surface Roughness, Oxide Film Structure

\section{1. 緒 言}

プリント配線板やICパッヶージ等において，電極として 用いられる銅と樹脂との接着性を良好に保つことは，気密 性の保持や機器の信頼性を確保するために大変重要であ る。しかしながら，一般に銅は酸化されやすく，室温にお いてもその表面は $\mathrm{Cu}_{2} \mathrm{O}$ などの酸化膜に覆われており ${ }^{1)}$, 樹 脂と銅との接合は酸化膜を介して行われるので, その剥離 は大きな問題となる。酸化膜の銅母材に対する密着性を向 上させるためには, 酸化膜の発生と剥離の機構に関する基 礎的な知見を得ることが必要である。そこで今回，密着性 に影響すると考えられる因子として，合金組成や表面状態 に着目し, 純銅と各種の銅合金について, 酸化膜の剥離試 験, X線 $(\mathrm{XRD})$, 走査電子顕微鏡 $(\mathrm{SEM})$, 透過電子顕微鏡 (TEM), およびオージェ電子分光法(AES)による構造解析 を行い, 酸化膜の密着性向上のための指針を探ることとし た。

\section{2. 実験方法}

試料として, タフピッチ銅, リン脱酸銅，および，合金 元素添加銅を用いた。合金銅は, 純銅に $\mathrm{Ni}, \mathrm{Cr}, \mathrm{Al}, \mathrm{Ti}$, $\mathrm{Zn}, \mathrm{Sn}$ 添加して大気溶製によって作製し，Cu- $0.52 \% \mathrm{Ni}$, $\mathrm{Cu}-2.30 \% \mathrm{Ni}, \mathrm{Cu}-0.53 \% \mathrm{Al}, \mathrm{Cu}-2.03 \% \mathrm{Al}, \mathrm{Cu}-0.40 \% \mathrm{Ti}, \mathrm{Cu}-$ $1.93 \% \mathrm{Ti}, \mathrm{Cu}-0.48 \% \mathrm{Sn}, \mathrm{Cu}-2.25 \% \mathrm{Sn}, \mathrm{Cu}-0.5 \% \mathrm{Cr}, \mathrm{Cu}-2 \%$ $\mathrm{Cr}$ の組成の試料を得た。合金組成として分析值(mass\%)を 示したが, Crの場合は, 溶解しにくく偏析を生じたため, 仕込み組成で示した。酸化膜の生成は, 電気炉を用いて大 気中で行った。

酸化膜の剥離試験は, 試験片の表面粗さを統一した場合

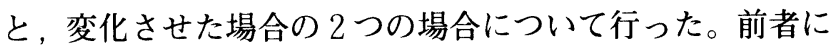
おいては, 合金銅, タフピッチ銅, リン脱酸銅の冷延板 (0.25mm厚) に表面研磨（\#600エメリ一紙）を施し， $20 \mathrm{~mm} \times 30 \mathrm{~mm}$ に整形の後, 洗浄・乾燥にて作製した試験 片を用いた。試験片の酸化は，300，350，400Cの各温度 
で 5 min行った。剥離試験は, 試験片にプラスチック粘着 テープ（住友スリーエム製\#851）を貼り付けて酸化膜を引 き剥がすことによって行い，剥離面積を画像解析装置で測 定した。後者においては，タフピッチ銅 $(20 \mathrm{~mm} \times$ $20 \mathrm{~mm} \times 2 \mathrm{~mm}$ ）を用い，その表面粗さを，エメリー紙 (\#150, \#600, \#1200) とバフ研磨 $(0.05 \mu \mathrm{m}$ アルミナ砥粒) で 4 段階に調整後，洗浄，乾燥して試験片を作製した。酸 化膜は， $400^{\circ} \mathrm{C}, 10 \mathrm{~min} の$ 加熱により生成させ，粘着テー プによる剥離試験を行った。

酸化膜厚は, 定電流で酸化膜を還元し, 単位面積当たり の還元に要した電気量を測定することによって評価した2)。

TEM(HITACHI-H800, JEOL-2000FX, 200kV)観察では， 基材から剥離させて得た酸化膜と酸化膜一基材断面切片の $2 つ の$ 観察を試みた。前者ではダイヤモンド砥粒 $(1 \mu \mathrm{m})$ により鏡面研磨した Cu-Tiと Cu-Cr試験片 $(30 \mathrm{~mm} \times$ $30 \mathrm{~mm} \times 2 \mathrm{~mm}$ ） $50 \mathrm{vol} \%$ リ酸水溶液で電解研磨し，蒸 留水によって洗浄した後, $400^{\circ} \mathrm{C} に て$ 加熱し, 生成した酸 化膜をナイフエッジによって剥離させて観察に用いた。後 者では，アルミナ砥粒 $(1 \mu \mathrm{m})$ により鏡面研磨したタフピ ッチ銅 $(0.4 \mathrm{~mm}$ 厚 $)$ を $300^{\circ} \mathrm{C} て ゙ 10 \mathrm{~min}$ 酸化させ,アクリル樹 脂に包埋後, $3 \mathrm{~mm} \times 10 \mathrm{~mm}$ の大ささに切り出し, さらに ミクロトーム（日製産業製，Reichert ULTRACUT S）によ り切り出して $10 〜 15 \mathrm{~nm}$ 厚の薄膜を得た。

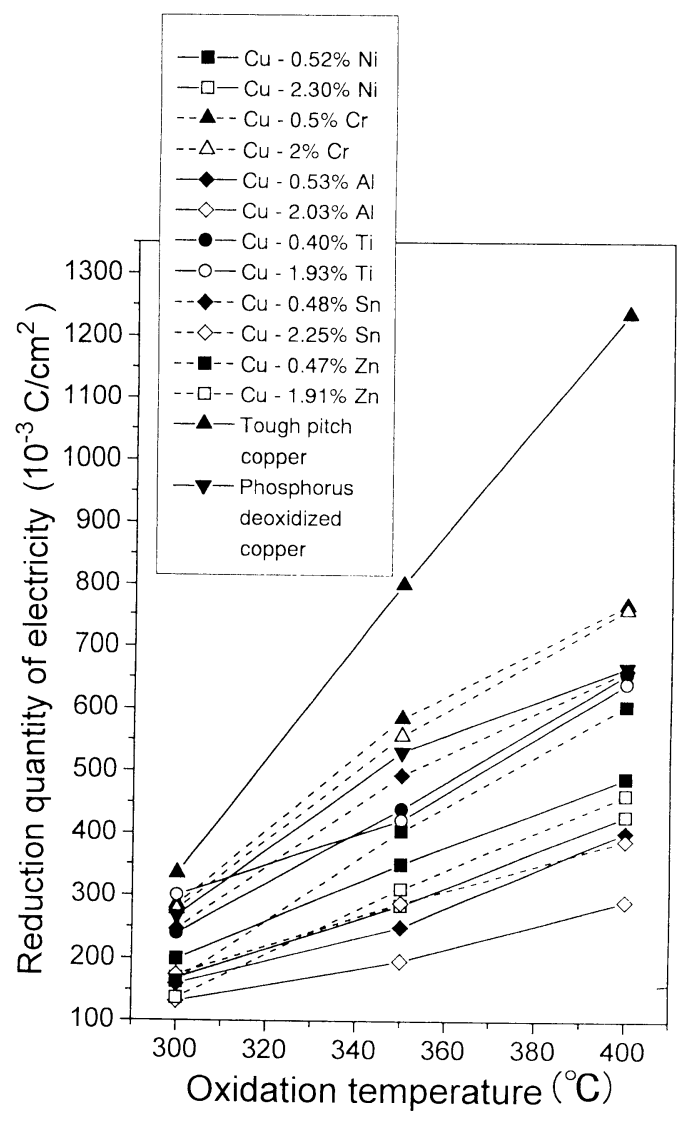

Fig.1 Relationship between the oxidation temperature and the oxide film thickness of pure copper and copper alloys
$\mathrm{XRD}$ 測定はCuK $\alpha$ 線により, $30 \mathrm{kV}, 20 \mathrm{~mA}$ 条件で行った。 AES分析（JEOL JAMP-7100E）では，ダイヤモンド砥粒 $(0.25 \mu \mathrm{m})$ による鏡面研磨の後, 脱脂, 洗浄したりン脱酸 銅（ $7 \mathrm{~mm} \times 7 \mathrm{~mm} \times 2 \mathrm{~mm} ）$ を $300^{\circ} \mathrm{C}$ で 5 min酸化させ， その表面を, アルゴンガスで1minずつスパッタエッチン グしつつ（加速電圧 $3 \mathrm{kV}$ ，イオン電流密度 $3 \times 10^{-5} \mathrm{~A} / \mathrm{cm}^{2}$ ), 深さ方向に組成分析した。

\section{3. 実験結果}

\section{1 酸化膜厚と酸化温度の関係}

図 1 にタフピッチ銅，リン脱酸銅および各種銅合金の酸 化温度と酸化膜の還元電気量との関係を示す。タフピッチ 銅が最も大きな還元電気量を示し，Cu-Alが最も小さい値 を示した。リン脱酸銅は, タフピッチ銅よりも値が小さく， むしろ他の合金の值に近い。還元電気量の酸化膜厚 $\mathrm{t}(\mathrm{nm})$ への換算は, $1 \mathrm{~cm}^{2}$ 当たりの還元電気量を, $\mathrm{q}\left(\mathrm{mC} / \mathrm{cm}^{2}\right)$ として，酸化膜がすべてCuOの場合は，

$$
\mathrm{t}=0.644 \mathrm{q}(\mathrm{nm})
$$

酸化膜がすべて $\mathrm{Cu}_{2} \mathrm{O}$ の場合は，

$$
\mathrm{t}=1.227 \mathrm{q}(\mathrm{nm})
$$

となる。後で述べるように, 銅酸化膜は, 必ずしも $\mathrm{CuO}$ も しくは $\mathrm{Cu}_{2} \mathrm{O}$ 単体のみからなるのではないので, 膜厚は, (1)式と (2)式で示される中間の值をとっていることになる。 そこで, 本論文では, 酸化膜厚を還元電気量の值により表 示することとする。

\section{2 酸化膜の剥離試験}

3.2 .1 各種銅合金の酸化膜の密着性と膜厚との関係 図 2 に剥離試験の結果を, 試験片面積に対する酸化膜の

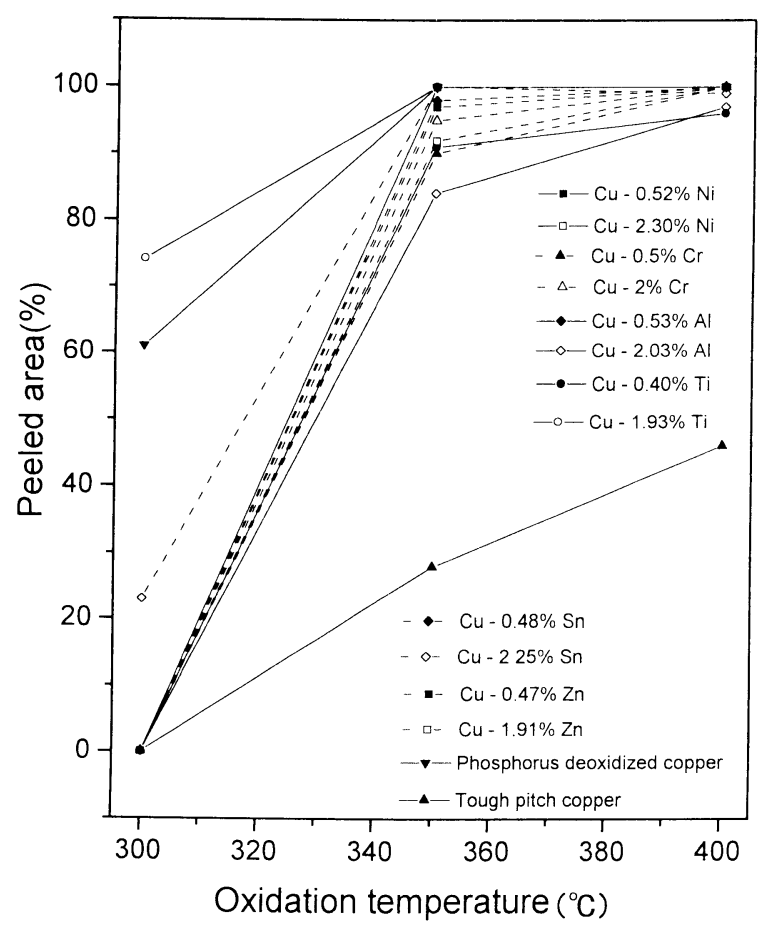

Fig.2 Relationship between the oxidation temperature and the peeled area of copper oxide films 
剥離面積の割合（剥離面積率（\%)）と酸化温度の関係と して示す。いずれの試料も，酸化温度の上昇に対応して剥 離面積率が增加しているが，Cu-1.93\% Ti（1.93Ti合金）と リン脱酸銅の酸化膜が目立って剥離しやすいことがわか る。

図 3 に図 1 と図 2 から求められた酸化膜厚と剥離面積率 との関係を示す。図 2 の場合と同様, タフピッチ銅は最も 剥離面積率が小さく，膜厚と剥離面積率がほぼ直線関係に あるのに対して, リン脱酸銅と合金銅は，小さな膜厚で急 激な剥離面積率の増加を示している。また, 最も小さい酸 化膜厚を示したCu-2.03\%Al合金（2.03\%Al合金）では，著 しく剥離しやすい酸化膜を生じる結果となった。

これらの結果より，合金化により酸化膜厚の増加を抑制 し得る反面, 酸化膜の密着性が低下したことがわかる。純 銅同士を比較すると, リン脱酸銅はタフピッチ銅に比べて 大変剥離しやすい酸化膜を生じることがわかった。

3. 2.2 タフピッチ銅の酸化膜の密着性と表面粗さとの 関係

表 1 に酸化試験前のタフピッチ銅の表面粗さ測定結果を 示す。 $\mathrm{R}_{\text {max }}$ (最大高さ), $\mathrm{R}_{\mathrm{z}}$ (10点平均粗さ), $\mathrm{R}_{\mathrm{a}}$ (中心線 平均粗さ）の值はいずれも，研磨紙の粗さが低下するに従 って低下していることがわかる。図 4 に，400年，10 min の加熱により生成した酸化膜の粘着テープによる剥離試験 の結果を示す。横軸は試験前の生成酸化膜厚, 縦軸は試験 後の試験片に残った酸化膜厚とテープ側に移着した酸化膜

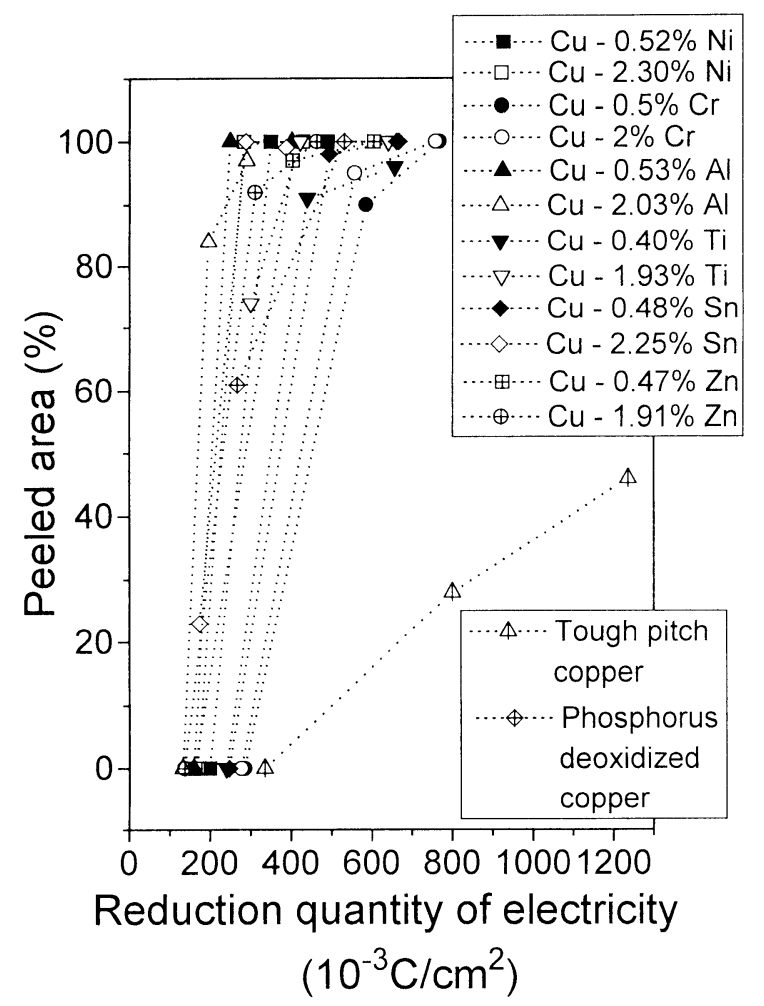

Fig.3 Relationship between the thickness of copper oxide films and the peeled area deduced from Fig.1 and Fig.2
Table 1 Surface roughness of the tough pitch copper specimens used for the peeling test

\begin{tabular}{l|c|c|c}
\hline & $\mathrm{R}_{\max }(\mu \mathrm{m})$ & $\mathrm{R}_{\mathrm{z}}(\mu \mathrm{m})$ & $\mathrm{R}_{\mathrm{a}}(\mu \mathrm{m})$ \\
\hline$\# 150$ & $15.8 \pm 4.5$ & $10.9 \pm 2.1$ & $1.84 \pm 0.025$ \\
\hline$\# 600$ & $2.17 \pm 0.13$ & $1.84 \pm 0.14$ & $0.268 \pm 0.024$ \\
\hline$\# 1200$ & $1.054 \pm 0.230$ & $0.777 \pm 0.118$ & $0.090 \pm 0.008$ \\
\hline buff & $0.090 \pm 0.019$ & $0.049 \pm 0.012$ & $0.011 \pm 0.002$ \\
\hline
\end{tabular}

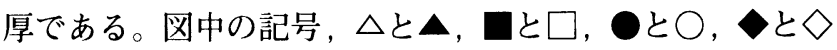
は，それぞれ，同一試験片における結果を示す。生成酸化 膜厚を見ると，\#600と\#1200のエメリー紙による表面仕上 げの場合は（\#600試料，\#1200試料)，\#150のエメリー紙に よる場合（\#150試料）に比べて膜厚が小さくなっているの に対し, 表面粗さの最も小さいバフ研磨の試料 (バフ試料) では，最も大きな膜厚を示している。表面粗さと酸化膜厚 の関係は単純ではないことがわかる。また, 生成酸化膜厚 が大きいほど試験片に残された膜厚は大きくなり，逆に， テープに移着した膜の厚さは小さくなっていることがわか る。この結果は, 生成酸化膜が厚いほど膜一基材界面で剥 離が生じにくくなったことを示しており，図3の結果と逆 の傾向にある。

\section{3 酸化膜のXRD,SEMおよびTEMによる解析}

\subsection{1 タフピッチ銅の酸化膜}

3. 2.2 の1200とバフ試料につき, 剥離試験前の酸化膜表 面のSEM写真を図 5 に示す。\#1200試料では，研磨条痕が 酸化膜に残っており，また，酸化膜がところどころで剥離 している様子が見られる。バフ試料では，酸化膜の表面は 平滑であり, また, 酸化膜の剥離は観察されない。
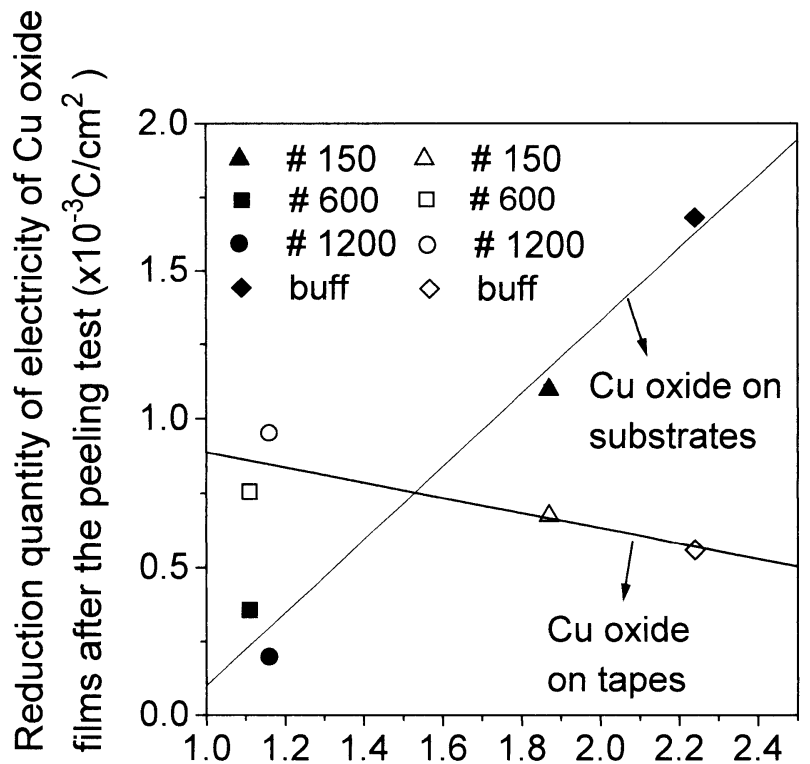

Reduction quantity of electricity of $\mathrm{Cu}$ oxide films on Cu substrates before the peeling test $\left(10^{-3} \mathrm{C} / \mathrm{cm}^{2}\right)$

Fig.4 Thickness of copper oxide films after the peeling test as a function of the thickness of copper oxide films formed by the oxidation at $400^{\circ} \mathrm{C}$ for $10 \mathrm{~min}$ 


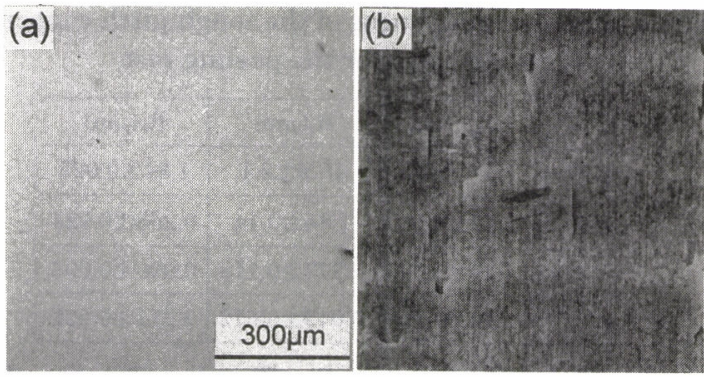

Fig.5 SEM images of the tough pitch copper specimen surfaces ((a)buff and (b)\#1200) oxidized at $400^{\circ} \mathrm{C}$ for $10 \mathrm{~min}$

図 6 に剥離試験前の各試験片の酸化膜厚と, X線回折に より得られた $\mathrm{Cu}_{2} \mathrm{O}(111)$ 線と $\mathrm{CuO}(111)$ 線の強度比の関係 $\left(\mathrm{I}(\mathrm{CuO}(111)) / \mathrm{I}\left(\mathrm{Cu}_{2} \mathrm{O}(111)\right)\right)$ を示す。最も表面粗さの小 さいバフ試料で強度比が小さくなっているが，エメリ一紙 で研磨した試料の間では, 表面粗さが大きい\#150試料の值 の方が, \#600と\#1200試料の值よりも小さくなっており, 強度比の大小を表面粗さのみで整理することができないこ とがわかる。酸化膜厚が大きいほど強度比が小さくなって いるので, 膜厚が大きい場合は $\mathrm{CuO}$ の生成量が相対的に少 なくなっていると判断される。

また, 図 7 に, 剥離試験後に試験片に残された酸化膜厚 と, 剥離試験前の酸化膜の $\mathrm{I}(\mathrm{CuO}(111)) / \mathrm{I}\left(\mathrm{Cu}_{2} \mathrm{O}(111)\right)$ との 関係を示す。眓から $\mathrm{CuO}$ 生成量が少ないものの方が, 残存 酸化膜が厚い, すなわち, 剥離しにくいと判断される。

困 8 に, $300^{\circ} \mathrm{C}, 10 \mathrm{~min}$ 加熱によるタフピッチ銅の酸 化膜の断面観察を示す。回折図形は $\mathrm{Cu}_{2} \mathrm{O}$ を示している。 $\mathrm{Cu}_{2} \mathrm{O}$ の111反射による暗視野像（b）では，表面近傍で， 酸化膜が柱状に生成したことがわかる。また, 酸化膜は成 長の際に層構造を形成したと考えられる。

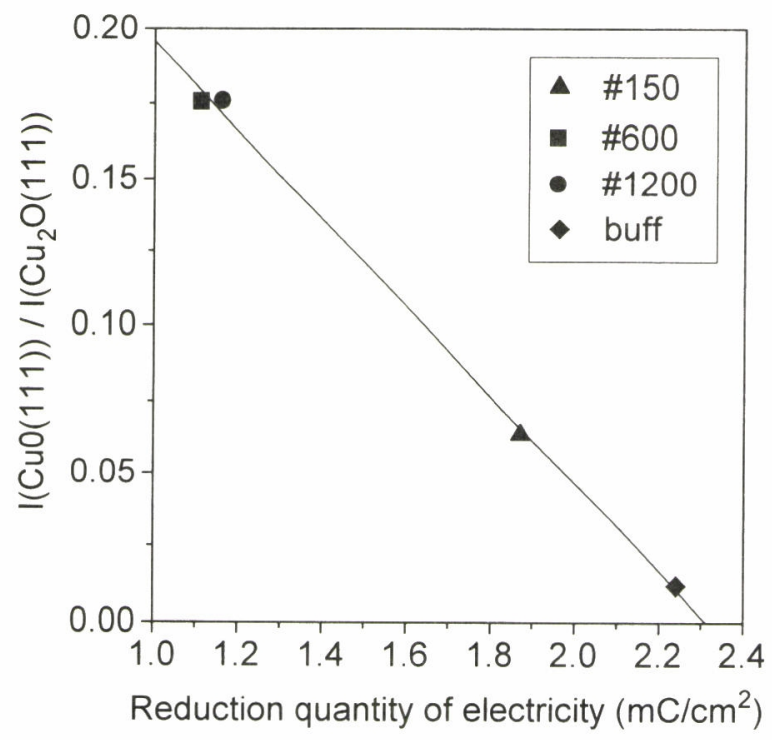

Fig.6 XRD intensity ratio $I(\mathrm{CuO}(111)) /\left(\mathrm{Cu}_{2} \mathrm{O}(111)\right)$ of the oxide films of tough pitch copper oxidized at $400^{\circ} \mathrm{C}$ for $10 \mathrm{~min}$ as a function of the oxide film thickness

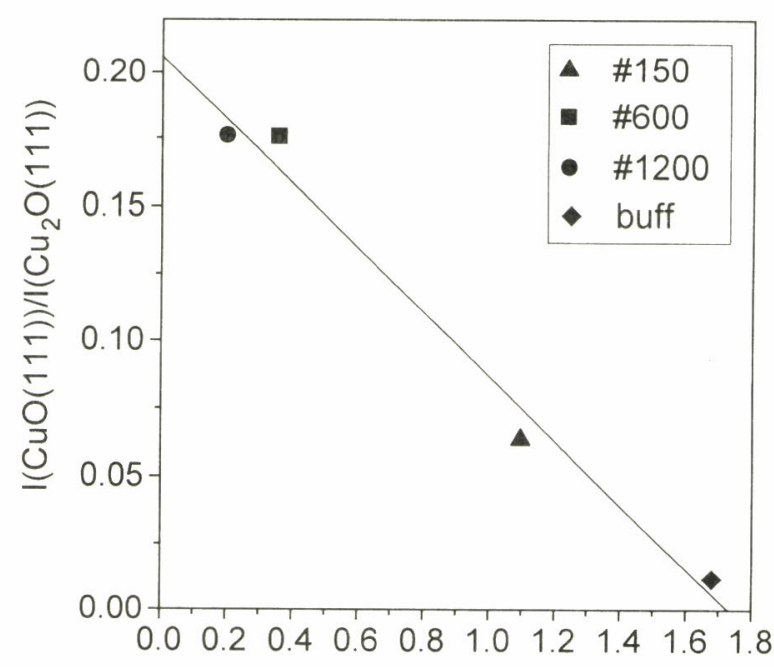

Reduction quantity of electricity $\left(\mathrm{mC} / \mathrm{cm}^{2}\right)$

Fig.7 XRD intensity ratio $\|(\mathrm{CuO}(111)) /\left(\mathrm{Cu}_{2} \mathrm{O}(111)\right)$ of the oxide films of tough pitch copper oxidized at $400^{\circ} \mathrm{C}$ for $10 \mathrm{~min}$ as a function of the oxide film thickness left on the substrates after the peeling test

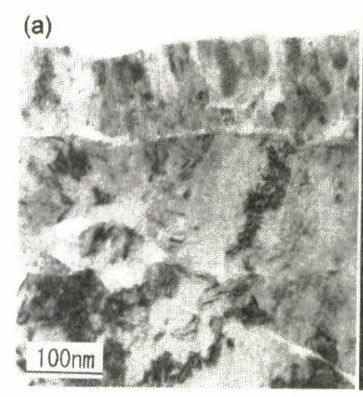

a) bright-field image

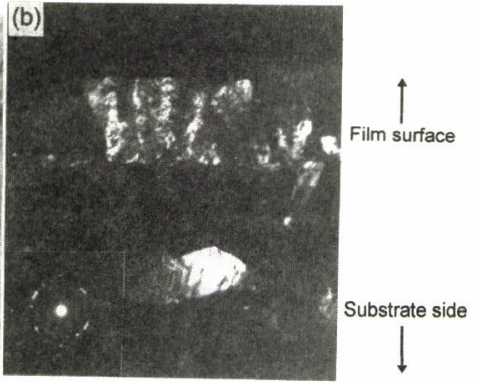

b) dark-field image
Fig.8 Cross-sectional TEM image of a tough pitch copper oxidized at $300^{\circ} \mathrm{C}$ for $10 \mathrm{~min}$

\subsubsection{Cu-TiおよびCu-Cr合金の酸化膜}

$\mathrm{Cu}-0.4 \% \mathrm{Ti}$ 合金（0.4Ti合金）, $1.93 \mathrm{Ti}$ 合金および $\mathrm{Cu}-2 \% \mathrm{Cr}$ 合金 (2Cr合金) の $400^{\circ} \mathrm{C}, 30 \mathrm{~min}$ の酸化により得た酸化膜 のTEM観察結果を, 図 9 〜図14に示す。困 9 は0.4Ti合金 の粒界 3 重点近傍で剥離した酸化膜, 図10（a）は同じ酸 化膜の拡大図，（b）は（a）の暗視野像である。基材の粒 界部に沿って酸化膜が厚く発達したことがわかり，また， 膜内部では針状組織が観察されている。回折図形はCuOを

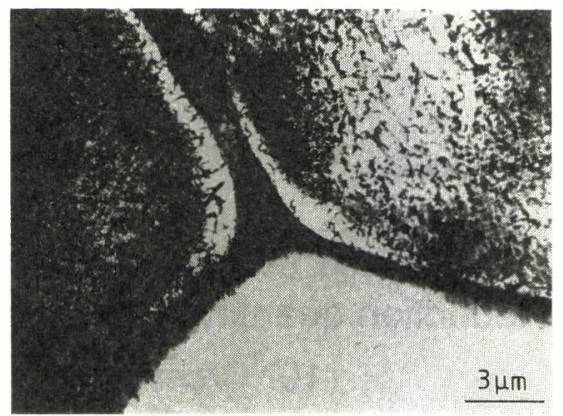

Fig.9 TEM image of a stripped oxide film around a triple junction of $\mathrm{Cu}-0.4 \% \mathrm{Ti}$ alloy oxidized at $400^{\circ} \mathrm{C}$ for $30 \mathrm{~min}$ 


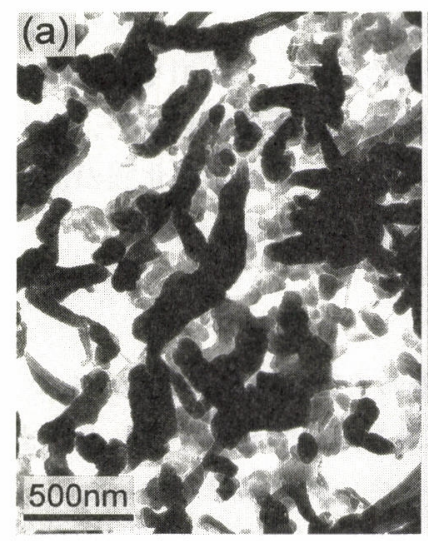

a) bright-field image

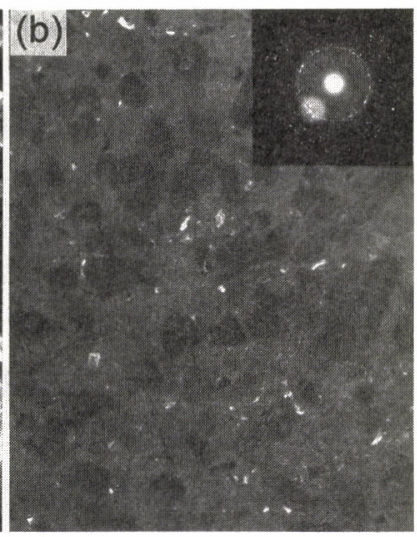

b) dark-field image
Fig.10 Magnified images of Fig.9

示しており，暗視野像で観察される $\mathrm{CuO}$ 粒径はたかだか $100 \mathrm{~nm}$ 程度である。図11は0.4Ti合金の双晶境界に沿って酸 化膜が破れたことを示す写真である。これらの結果は，銅 の粒界や粒界 3 重点が酸化膜の発達にとって重要な場所で あることを示している。Cu-Al-Si合金では，酸化物の核が 結晶粒界や双晶境界から生成し始めると報告されており ${ }^{3)}$, 粒界や双晶境界が酸化膜の成長に強く関わっていることが 今回の観察からも支持される。

図11では，針状組織は観察されず，同一試料において酸 化膜はさまざまな形態をとることがわかる。罒12では

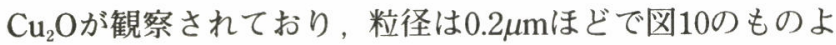

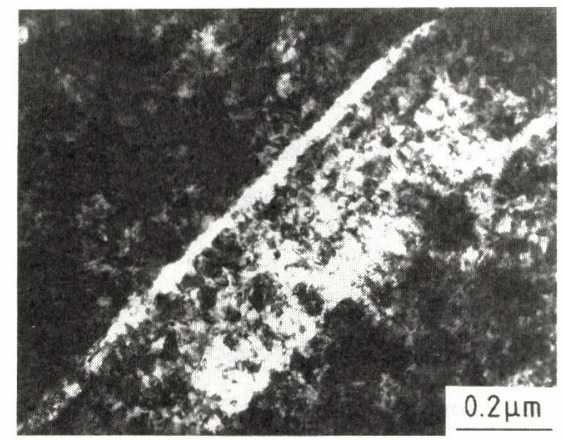

Fig.11 TEM image of a stripped oxide film near a twin boundary of $\mathrm{Cu}-0.4 \% \mathrm{Ti}$ oxidized at $400{ }^{\circ} \mathrm{C}$ for 30 $\min$

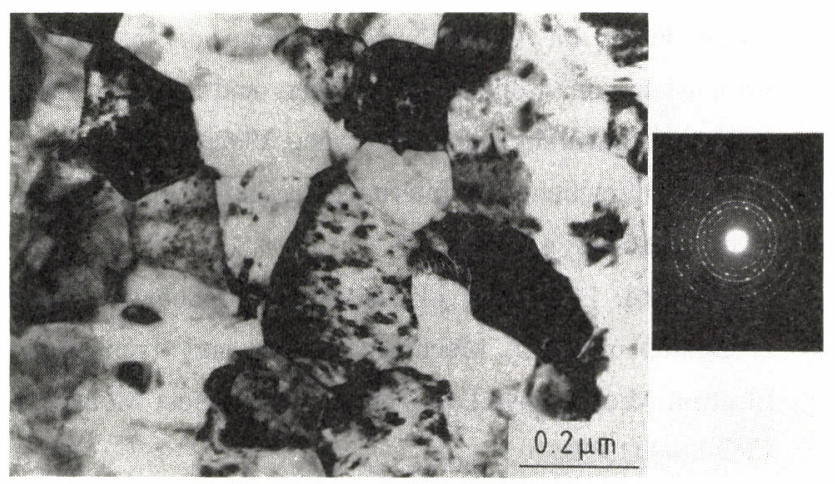

Fig.12 TEM image of a stripped oxide film of $\mathrm{Cu}-0.4 \% \mathrm{Ti}$ oxidized at $400{ }^{\circ} \mathrm{C}$ for $30 \mathrm{~min}$
りも大きい。また，多数のボイドと考えられるコントラス トが観察されている。眓13に1.93Ti合金の酸化膜を示す。 酸化膜は $0.1 \mu \mathrm{m}$ ほどの結晶粒から成っており，回折図形は $\mathrm{CuO}$ を示している。図14に2Cr合金の酸化膜を示す。粒径 は0.1 $\mu \mathrm{m}$ ぼであり，回折図形はCuOの生成を示している。

以上より，TiやCrなどの合金元素添加量を増加させると

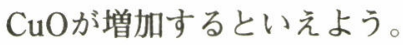

\section{4. リン脱酸銅のAES分析}

図15に，リン脱酸銅表面のAES分析結果を，縦軸に酸素 と銅の原子数比を，横軸にスパッタ回数をとって示す。酸 化膜の表面ではCuOの組成に近いが，基材に近づくにした がって, $\mathrm{Cu}_{2} \mathrm{O}$ の組成を経て酸素が減少していることがわ かる。99.99\% Cuの $178^{\circ} \mathrm{C}, 5$ min酸化のXPS分析では, 酸 化膜が $\mathrm{Cu}_{2} \mathrm{O}$ と $\mathrm{CuO}$ から成る様子が観察され，かつ， $\mathrm{CuO}$

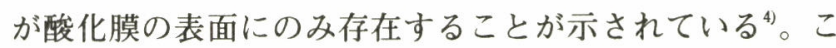
の結果は, 今回と同様の傾向にある。

\section{5. 考 察}

四 1 で見たように，リン脱酸銅と合金試料はタフピッチ 銅よりも小さな酸化膜厚を示し, また, リン脱酸銅と合金 銅の酸化膜の密着性は, タフピッチ銅の場合に比べて劣っ ていた（図２，3）。2.03\%Al合金は最も薄い酸化膜厚を 示すとともに, 剥離しやすい酸化膜を生じた（図 1,2 , $3)$ 。

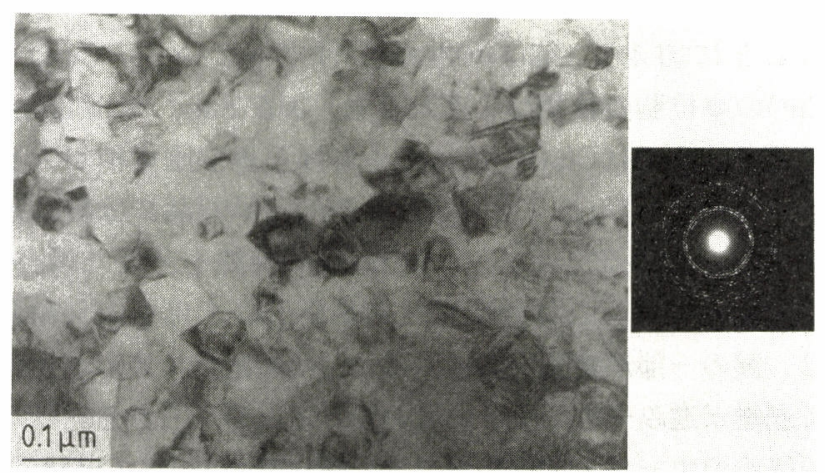

Fig.13 TEM image of a stripped oxide film of Cu-1.93\% Ti oxidized at $400^{\circ} \mathrm{C}$ for $30 \mathrm{~min}$

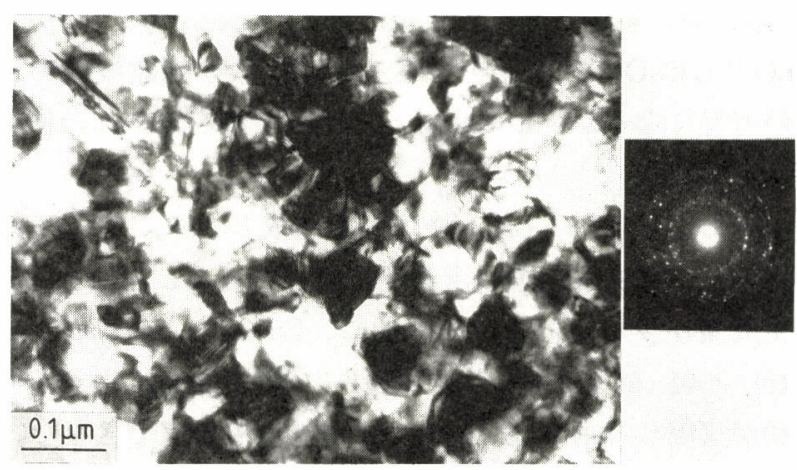

Fig.14 TEM image of a stripped oxide film of $\mathrm{Cu}-2 \% \mathrm{Cr}$ oxidized at $400{ }^{\circ} \mathrm{C}$ for $30 \mathrm{~min}$ 


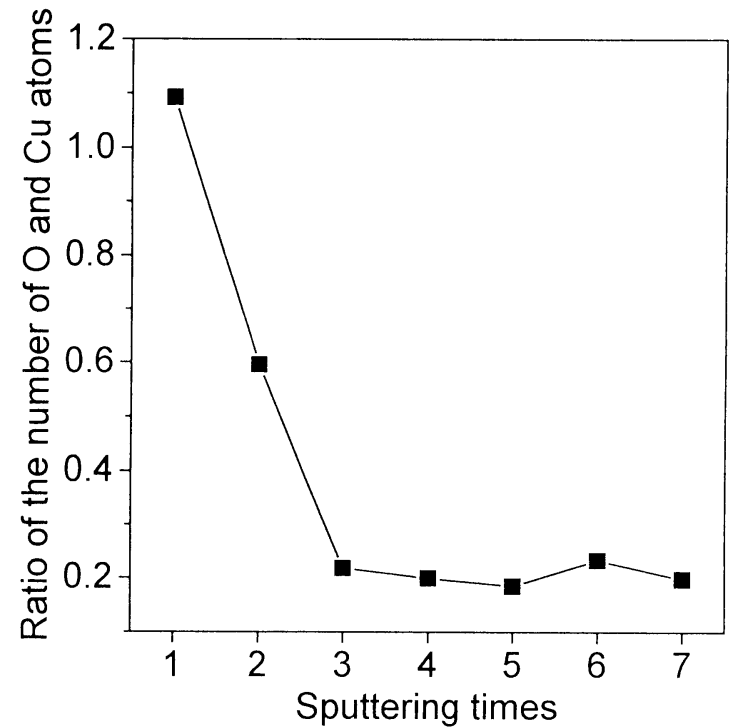

Fig.15 Ratio of $\mathrm{O}$ and $\mathrm{Cu}$ atoms at the surface of phosphorus deoxidized copper oxidized at $300^{\circ} \mathrm{C}$ for $5 \mathrm{~min}$ as a function of sputtering times

同じタフピッチ銅においても，エメリー紙により研磨さ れた表面粗さの大きい試料では, 表面粗さが小さいバフ研 磨試料よりも酸化膜厚が小さく, 酸化膜の密着性が劣って おり，かつ， $\mathrm{CuO}$ の生成量が増加していた（図 4，5，6， 7 )。タフピッチ銅では $\mathrm{Cu}_{2} \mathrm{O}$ が主として見出されたのに対 し（図 4，6，7，8），Cu-TiにおいてはTiを増加させる

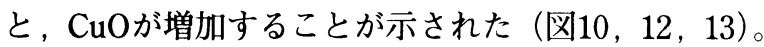

酸化膜の密着性に劣る試料では, 酸化膜はより薄膜であ ることに加えて, $\mathrm{CuO}$ の生成が目立っている。 $\mathrm{Cu}_{2} \mathrm{O}$ と

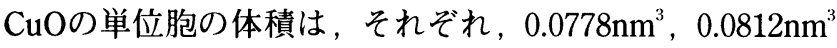
であり， $\mathrm{CuO}$ は $\mathrm{Cu}_{2} \mathrm{O}$ に比べて $4 \%$ ほど単位胞体積が大き く，しかも， $\mathrm{Cu}_{2} \mathrm{O}$ (立方晶) と $\mathrm{CuO}$ (単斜晶) は結晶系 が異なっている ${ }^{5}$ 。 $\mathrm{Cu}_{2} \mathrm{O}$ から $\mathrm{CuO}$ への変態を考えた場合， このような大きな体積変化と結晶格子の変化を伴う場合 は，膜の一部が変態を開始すると，その近傍で歪みが生じ て剥離が進みやすくなる環境が生じると考えられる。リン 脱酸銅のオージェ分析結果では，酸化膜表面ではCuOが認 められ，かつ，内部ではより還元的に推移していたので， 表面から内部に向かってCuOへの変態が進行することによ り,酸化膜が剥離しやすい状態になったことが考えられる。 $\mathrm{Cu}_{2} \mathrm{O}$ から $\mathrm{CuO}$ への変態を考えると酸化膜の剥離機構の説 明が容易になるが，この点は，今後解析例を增やした検証 が必要である。

主として $\mathrm{Cu}_{2} \mathrm{O}$ から成る酸化膜が生成したタフピッチ銅 において，最も酸化膜の密着性が良好だったことは， $\mathrm{CuO}$

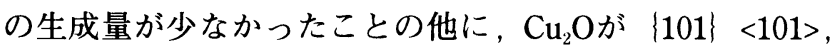
$\{110\}<001>$ な゙のすべり系を持ち ${ }^{6}$, 塑性変形による応力 緩和が実現して密着性が向上した可能性も否定できない。
タフピッチ銅の断面TEM観察において，酸化膜一基材 界面に薄い非晶質相の存在が認められ，この相を介しての 酸化膜と基材との密着性も検討すべき問題であるが，以上 の観察解析結果をまとめると, $\mathrm{CuO}$ の生成が酸化膜の密着 性の低下に深く関与していると考えられる。

\section{6. 結 論}

1. タフピッチ銅, リン脱酸銅および各種銅合金のうちで, タフピッチ銅の酸化膜が最も高い密着性を示した。ま た, タフピッチ銅が最も大きい酸化膜厚を示した。

2. タフピッチ銅において, 酸化膜が厚い場合は $\mathrm{Cu}_{2} \mathrm{O}$ が 主として観察された。CuOの生成は，密着性の低い薄 い酸化膜の場合に，より多く見出された。

3. Cu-Ti合金において，合金元素の増加により， $\mathrm{CuOが}$ より高頻度に観察された。

4. $\mathrm{CuO}$ の生成か酸化膜の密着性の低下に深く関与してい ると考えられる。

銅酸化膜の密着性は，合金組成と表面状態に大きく依存 する。酸化膜の密着性の向上には，これらの点を考虑した より詳細な研究が必要である。

\section{謝 辞}

酸化膜の機器分析にご協力いただいた東京大学工学部金 属工学科の中村光弘氏に感謝いたします。

(1996.1.12-受理１996.4.26-再受理)

\section{文献}

1) M.D.Sanderson and J.C.Scully: "Room Temperature Oxidation of $\mathrm{Cu}$ and Some Cu Alloys", Corrosion Science, 10, 55-57 (1970)

2）山根寿己, 辰巳 敏, 平尾桂一: “酸化銅膜の電気化学的 研究”，伸銅技術研究会誌，14，114-119（1975）

3) M.D.Sanderson and J.C.Scully : "The Initial Stages of Oxide Film Formation on Copper and Some Copper Alloys", Corrosion-Nace, 25, 291-299 (1969)

4) K.Kobayashi, K.Shimizu, G.E.Thompson and G.C.Wood: "Direct Observation of the Mosaic Structure of Thermal Oxide Films on Copper", Proceedings of International Symposium on Control of Copper and Copper Alloys Oxidation,University of Rouen, France, 1992, pp.21-26

5) Powder Diffraction File, International Center for Diffraction Data, USA,5-667, 41-254

6) A.Audouard, J.Castaing, J.P.Riviere and B.Sieber: "Plastic Properties of $\mathrm{Cu}_{2} \mathrm{O}$, Mechanical Tests and Transmission Electron Microscopy-I.Low Temperature”, Acta Metall., 29, 1385-1400 (1981) 